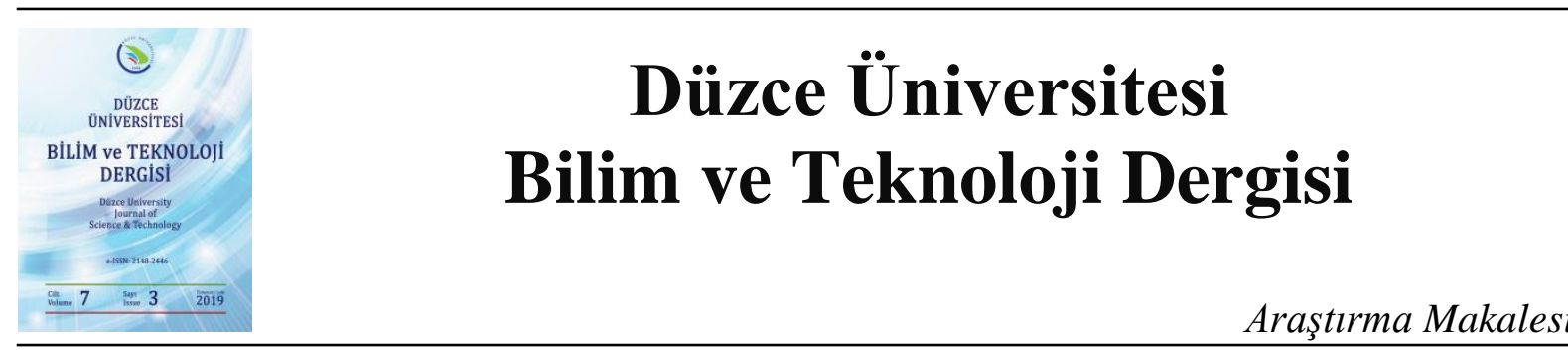

\title{
Düzce ve Yakın Çevresindeki Bazı Endemik Bitki Türlerinin Mevsimsel Değişim Potansiyelinin Belirlenmesi
}

\author{
(iD Engin EROĞLU ${ }^{a}$, iD M. Kıvanç AK ${ }^{a}$, iD Şemsettin KULAÇ ${ }^{a}$, iD Bilal ÇETİN ${ }^{a}$, iD Sertaç $\mathrm{KAYA}^{*}$, \\ IDHarun AYDIN ${ }^{a}$, ID Nermin BAŞARAN ${ }^{a}$, iD Tuba DOGAN ${ }^{a}$, ID Alperen MERAL ${ }^{b}$
${ }^{a}$ Peyzaj Mimarlı̆̆ Bölümü, Orman Fakültesi, Düzce Üniversitesi, Düzce, TÜRKIYYE
${ }^{b}$ Peyzaj Mimarlı̆̆ Bölümü, Ziraat Fakültesi, Bingöl Üniversitesi, Bingöl, TÜRKIYE
* Sorumlu yazarın e-posta adresi: sertackaya@duzce.edu.tr
DOI : 10.29130/dubited.551678
}

\section{$\underline{\text { ÖZET }}$}

Türkiye bitki çeşitliliği açısından oldukça zengin bir doğal bitki örtüsüne sahiptir. Yüksek çeşitlilikteki doğal bitki örtüsü içerisinde yer alan birçok ağaç, çalı ve otsu karaktere sahip bitki türleri bulunmaktadır. Doğal bitki türleri bulundukları coğrafyada kullanıldıklarında yöre koşullarına en iyi adapte olabilen türler olmaktadırlar. Peyzaj mimarlığı uygulamalarında bakım maliyetlerinin azaltılması, sağlıklı bir bitki dokusu sağlanması, yerel çevreye uyum, çevre kalitesinin iyileştirilmesi gibi nedenlerle doğal türlerin kullanılması büyük önem taşımaktadır. Türkiye'de özellikle doğal kaynak yönetimleri açısından yaşam birliktelikleri son derece önem kazanmaya başlamıştır. Özellikle Batı Karadeniz bölgesi gerek içermiş olduğu tür zenginliği ve gerekse de yaşam birliktelikleri çeşitliliği ile dikkat çekmektedir. Bu çalışmada Düzce Kent Merkezi çevresinde envanteri çıkarılmış olan endemik bitki türleri mevsimsel olarak gözlemlenmiş ve bu bitkilerin estetik ve fonksiyonel yönden kentsel alanlarda yapılacak olan peyzaj tasarımlarında değerlendirilme olanakları saptanmıştır.

Anahtar Kelimeler: Doğal bitki, Düzce, Endemik bitki, Mevsimsel Değişim Potansiyeli, Peyzaj Mimarlı̆̆l

\section{Determination of Seasonal Change Potential of Some Endemic Plant Species in Düzce and Its Surrounding Area}

\begin{abstract}
$\underline{\text { ABSTRACT }}$
Turkey has a very rich natural vegetation in terms of plant diversity. There are many trees, shrubs and herbaceous plant species in our high variety of natural vegetation. Natural plant species are the species that can best adapt to the local conditions when they are used in their geography. In landscape architecture applications, the use of natural species is of great importance due to reasons such as reducing maintenance costs, ensuring a healthy plant tissue, adapting to the local environment and improving the quality of the environment. especially in terms of life and coexistence of natural resource management in Turkey has gained utmost importance.
\end{abstract}

Geliş: 10/04/2019, Düzeltme: 15/05/2019, Kabul: 20/05/2019 
Especially the Western Black Sea region attracts attention with its richness and diversity. In this study, endemic plant species which have been stocked around Düzce City Center were observed seasonally and the possibilities of evaluating these plants in landscape designs to be made in the aesthetic and functional aspects of urban areas were determined.

Keywords: Duzce, Endemic plant, Landscape architecture, Nature plant, Seasonal change potential

\section{GiRiș}

$\mathrm{T}$ ürkiye bitki çeşitliliği açısından oldukça zengin bir doğal bitki örtüsüne sahiptir [1,2,3]. Yüksek çeşitlilikteki doğal bitki örtüsü içerisinde yer alan birçok ağaç, çalı ve otsu karaktere sahip bitki türleri bulunmaktadır [4]. Bu zengin floraya rağmen özellikle kentsel alanlarda halen egzotik bitki türlerinin yoğun olarak kullanılmaya devam ettiği görülmektedir [5]. Bu nedenle özellikle son y1llarda gerek uygulamalarda gerekse akademik çalışmalarda doğal bitki kullanımının önemi vurgulanmaya başlamıştır. Barış [6] doğal bitkiler ile ilgili yapmış olduğu çalışmada doğal bitkilerin estetik ve fonksiyonel özelliklerinin yanı sıra toprağın verimliliğini arttırdığını, erozyonu azalttıklarını ve egzotik bitkilere göre ekolojik ve bakım istekleri bakımından daha uygun olduğunu belirtmektedir.

Doğal bitki türleri bulundukları coğrafyada kullanıldıklarında yöre ekolojisine en iyi adapte olabilen türler olmaktadırlar [7]. Peyzaj uygulamalarında bakım maliyetlerinin azaltılması, sağlıklı bir bitki dokusu sağlanması, bulunduğu yöreye uyumu ve çevre kalitesinin iyileştirilmesi gibi nedenlerle doğal türlerin kullanılması oldukça önemlidir [8]. Gelecekte bunların özellikle çevre düzenlemelerinde kullanımları ve başta endemik türler olmak üzere peyzajda kullanılabilecek türlerin üretilmeleri, doğa korunması ve nesillerinin devamı açısından büyük yararlar sağlayacak böylece doğal bitkilerimizin gelecek nesillere kadar varlıklarını sürdürmelerini sağlanmasına katkıda bulunulacaktır [9].

Bunun doğal sonucu olarak doğal bitki türlerinin kullanımlarının yaygınlaştırılmasının gerekliliği ortaya çıkmaktadır. Ancak, bu amaçla kullanılacak bitki türlerinin genel özelliklerinin bilinmesi, peyzaj mimarlığı uygulamalarındaki değerlerinin irdelenmesi, bitkilendirme çalışmalarında bu türlerin hangi özellikleri ile kullanım potansiyeli taşıdıklarının belirlenmesi gerekmektedir [4].

Peyzaj tasarımlarında bitkiler çoğunlukla görünümleri ve kompozisyonları açısından ele alınmaktadırlar [10, 11]. Bitkisel tasarımın temeli olan bitkiler ise estetik veya fonksiyonel açıdan kullanım amacına yönelik olarak bulundukları mekânlara farklı anlamlar ve fonksiyonlar katmaktadır. $\mathrm{Bu}$ kompozisyonu oluşturabilmek için bitkilerin yapısal ve görsel özelliklerini iyi bilmek gerekmektedir. Bitkilerin en önemli işlevlerinden birisi estetik yani görsel algılama özellikleridir [12].

Odunsu bitkilerin estetik değerlerini ortaya koyabilmek için öncelikle sahip oldukları dendrolojik özelliklerinin, yani bitkinin habitusunun ve çeşitli organlarının (gövde, gövde kabuğu, dallar, yaprak, çiçek, meyve) biçim, ölçü, renk ve doku özelliklerinin bilinmesi önem taşımaktadır. Bu öğelerin çeşitli 
tasarım ilkeleri çerçevesindeki kompozisyonlar oluşturarak kalıcı ya da yıl içinde mevsimlere göre değişen görsel etkiler elde edilebilir [13]. Eroğlu ve ark. [14] yapmış oldukları çalışmada bitkilerin mevsimsel değişimleri ve kompozisyonları görsel tercihler için oldukça önemli olduğunu belirtmişlerdir.

Türkiye'de özellikle doğal kaynak yönetimleri açısından yaşam birliktelikleri son derece önem kazanmaya başlamıştır [14]. Özellikle Batı Karadeniz bölgesi gerek içermiş olduğu tür zenginliği ve gerekse de yaşam birliktelikleri çeşitliliği ile dikkat çekmektedir. Zengin bitkisel potansiyel olmasına rağmen, peyzaj çalışmalarında kullanılan bitki türü çeşitliliği oldukça azdır. Bu nedenle doğal bitkilerin peyzaj tasarımlarında kullanılması ve değerlendirilmesi açısından büyük bir eksiklik gözlenmektedir [15]. Bu çalışmada Düzce Kent Merkezi çevresinde envanteri çıkarılmış olan endemik bitki türleri mevsimsel olarak gözlemlenmiş ve bu bitkilerin estetik ve fonksiyonel yönden kentsel alanlarda yapılacak olan peyzaj tasarımlarında değerlendirilme olanakları saptanmıştır.

\section{MATERYAL ve METOD}

\section{A. MATERYAL}

Araştırma alanı olarak seçilen Düzce kenti ve çevresi bulunduğu coğrafya açısından önemli bir konuma sahiptir. Batı Karadeniz bölgesinde yer alıyor oluşu ve sahip olduğu iklimsel özellikler, bölgenin hem Karadeniz hem de Akdeniz iklimi etkisinde kalmasını sağlamaktadır. Bu durum bölgenin biyoçeşitliliğini arttırmakta, farklı toleranslara sahip bitki türlerinin bölgede yetişmesine imkân sunmaktadır. Bunun yanı sıra alan seçimi aşaması için Düzce ve yakın çevresindeki yüksek dağlık alanlar gezilmiş ve bu alanların görsel olarak incelemesi gerçekleştirilmiştir.

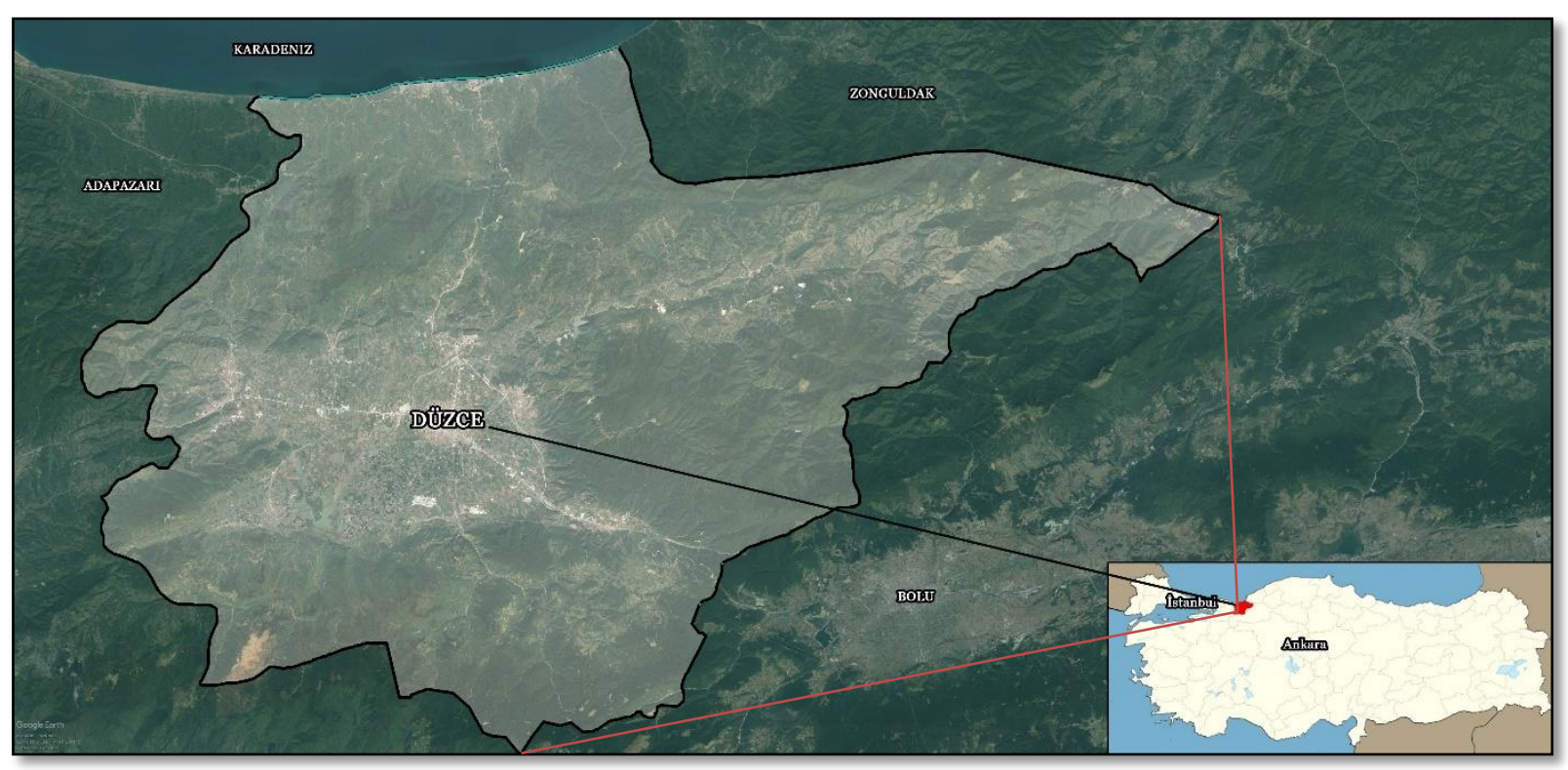

Şekil 1. Araştırma alanının konumu

Çalışmanın ana materyalini Düzce Kenti ve çevresindeki açık ve yeşil alanlarda bulunan endemik bitki taksonları oluşturmaktadır. 


\section{B. YÖNTEM}

Düzce İli Flora (Damarlı Bitkiler), Fauna (Kuşlar, Memeliler, Çiftyaşarlar, Sürüngenler, İçsu Balıkları) ve Habitat/ Ekosistem İzleme Çalışması'nda [16]; Anadolu Aklar otu (Lythrum anatolicum -Efteni Gölü), Düzce Pelemir Otu (Cephalaria duzceënsis N.Aksoy \& R.S.Göktürk-Emeksiz ve Aksu Deresi Havzas1), Düzce Peygamber Çiçeği (Centaurea yaltirikii N.Aksoy, H.Duman \& Efe subspGüzeldere Şelalesi-Emeksiz Havzas1) ve Seseli resinosum Freyn \& Sint, Düzce bölgesine özgü lokal endemik bitki taksonları olup öncelikle izlenmeye konu edinilmiştir.

Çalışma süresince her ay düzenli gidilen alanlarda türe ait popülasyon düzeyi gözlenmiş ve fotoğraflanmıştır. Tür düzeyinde izlemeye konu olan bitkilerin fenolojik potansiyellerini anlamak için, korunan habitatın peyzaj özelliklerinin mevsimsel değişimlerine göre gözlemler gerçekleştirilmiştir. Vejetasyon dönemlerine göre bitki taksonlarının fenolojik izleme raporları oluşturulmuştur. Çalışmanın son kısmında tespit edilen bitki taksonlarının mevsimsel değişime bağlı olarak peyzaj değerleri ortaya çıkarılmış ve peyzajda kullanım potansiyellerine yönelik öneriler getirilmiştir.

\section{BULGULAR ve TARTIȘMA}

Çalışma alanında yapılan gözlemler sonuncunda 4 türe ait bitki taksonları belirlenmiştir. Bunlar; Cephalaria duzceënsis, Centaurea yaltiriki, Lythrum anatolicum ve Seseli resinosum'dir. Tespit edilen endemik bitki taksonlarının bulundukları konumlar Şekil 2'de gösterilmiştir.

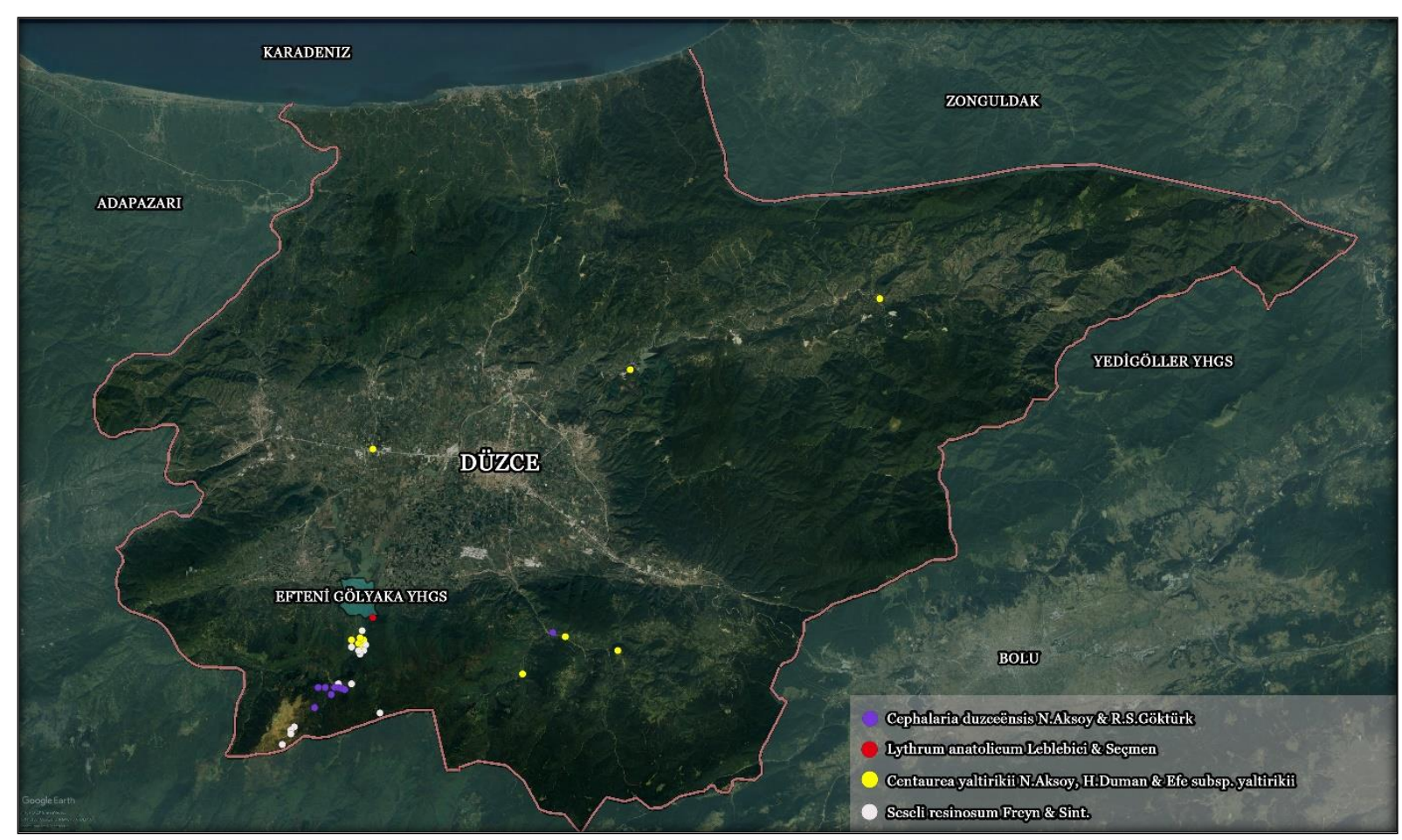

Şekil 2. Teşhis edilen türlere ait gözlem noktaları haritası 
Çalışma her ay düzenli gidilen alanlarda türe ait popülasyon düzeyi gözlenmiş ve fotoğraflanmıştır ve 2 vejetasyon dönemine (Haziran-Ekim) ait görseller aşağıda belirtilmiştir (Şekil 3,4,5,6).
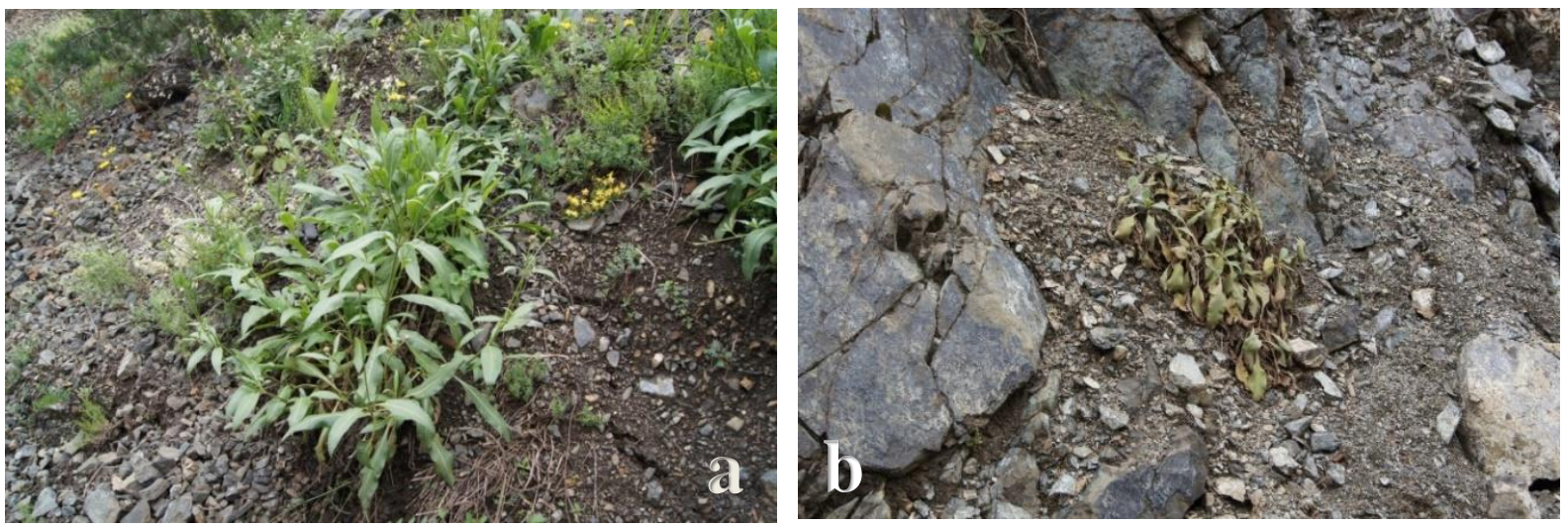

Şekil 3. Cephalaria duzceënsis N.Aksoy \& R.S.Göktürk arazi çalışmasına ait (a) Haziran ve (b) Ekim görselleri
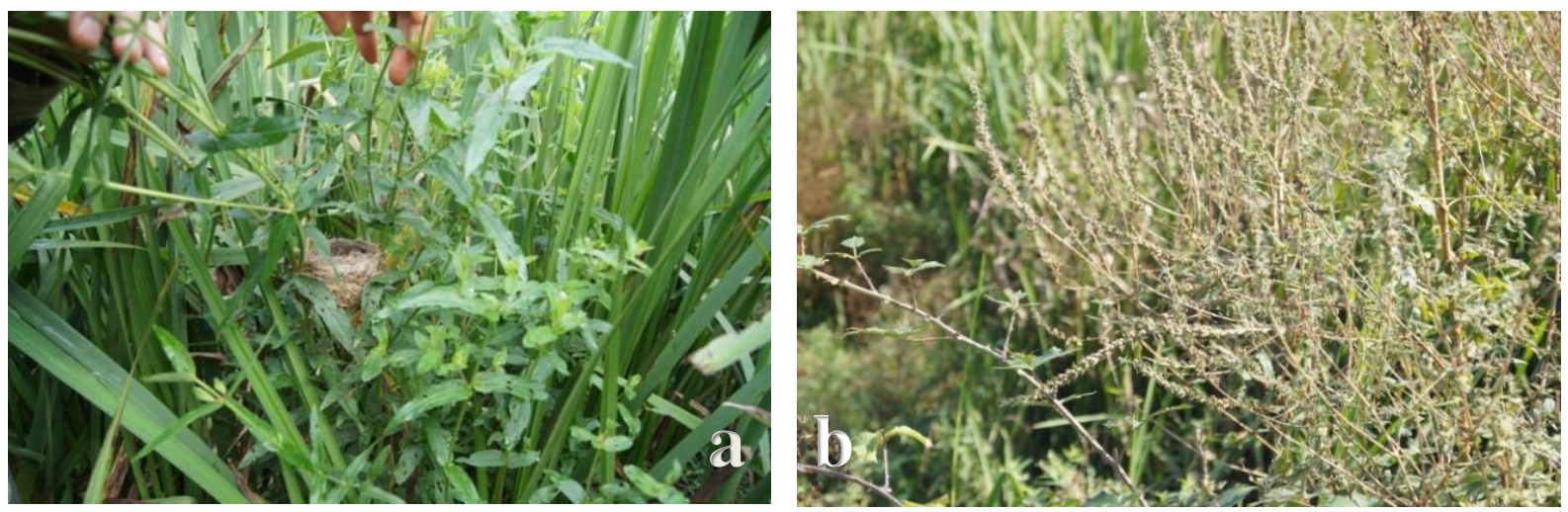

Şekil 4. Centaurea yaltirikii N.Aksoy, H.Duman \& Efe subsp. yaltirikii Arazi çalışmasına ait (a) Haziran ve (b) Ekim görselleri
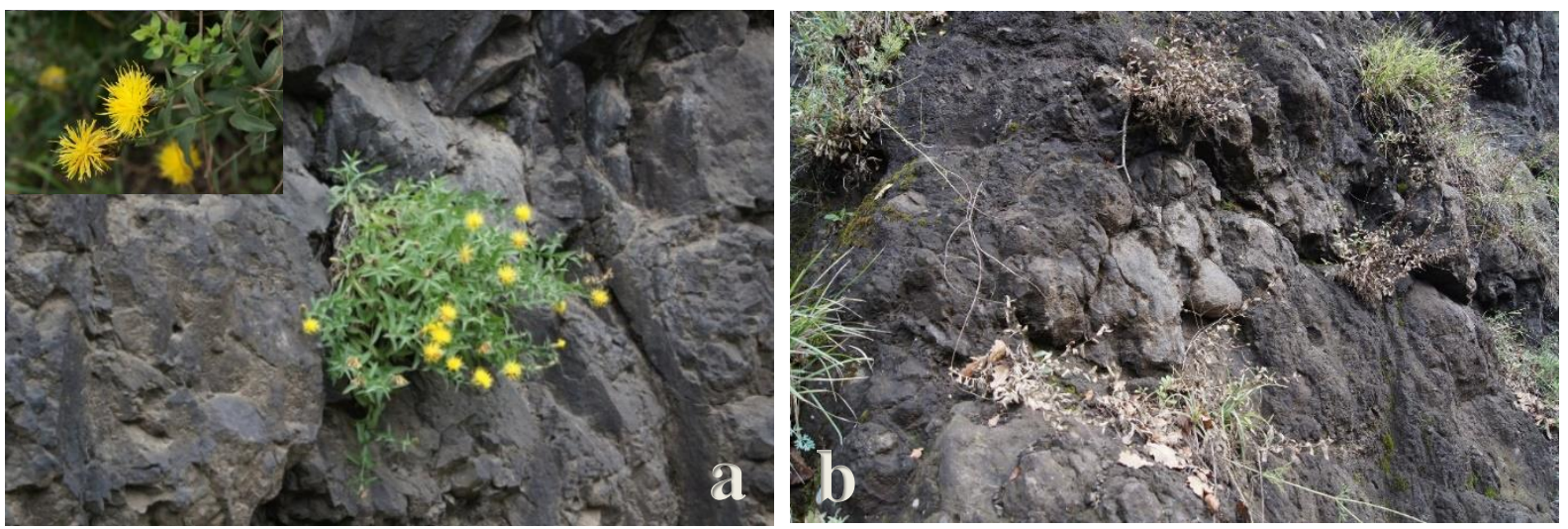

Şekil 5. Lythrum anatolicum Leblebici \& Seçmen Arazi çalışmasına ait (a) Haziran ve (b) Ekim görselleri 

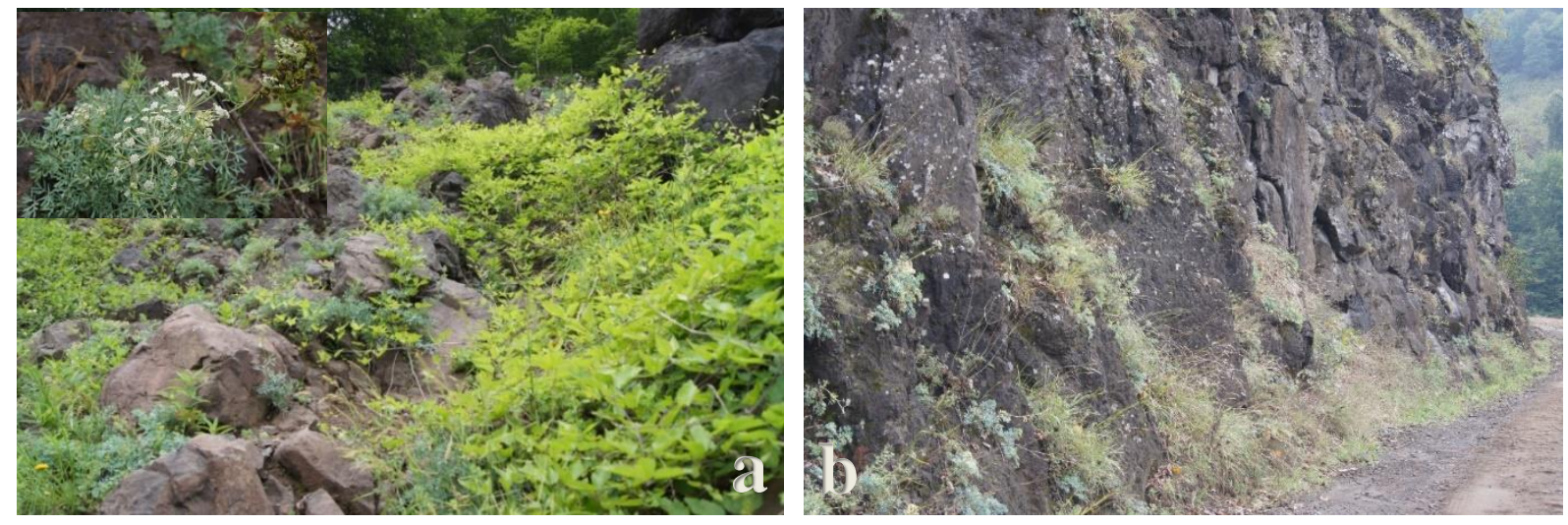

Şekil 6. Seseli resinosum Freyn \& Sint. Arazi çalışmasına ait (a) Haziran ve (b) Ekim görselleri

Endemik bitki taksonlarına ait tür ve habitat düzeyinde fenolojik gözlemler tamamlanmış ve bu alanların Haziran-Ekim aylarına ait genel değerlendirmeleri Tablo 1 ve Tablo 2 de verilmiştir.

Tablo 1. Bitki Taksonlarının İzleme Planı Arazi çalışması (Haziran)

\begin{tabular}{lllll}
\hline İzlenen & İzleme & İzleme & \\
Çalışma & Düzeyi & Zamanı & Başarı Göstergesi & İzleme Düzeyi \\
Konusu & & &
\end{tabular}

Cephalaria

duzceёnsis

N.Aksoy \&

R.S.Göktürk
Tür /

Popülasyon
Göstergeye konu olan tür yayılış gösterdiği yerlerde birim alanda;

Haziran Örtü derecesi sınıfi: 4-5

Örtüş oranı: \% 55-65

Sosyobilitesi: yama, parça ve küçük koloni
Bitki popülasyonu bulunduğu alan içerisinde özellikle Pinus sylvestris orman altı, sınırı ve açıklık-kayalık alanları üzerinde tek tek dağınık halde ya da küçük koloniler oluşturacak şekilde yayılış göstermektedir. Bu dönem içerisinde tür yeni yeni tomurcuklar oluşturmakta ancak çiçeklenme başlamamakta ve daha çok dikine bir form yapısı ortaya koymaktadır.

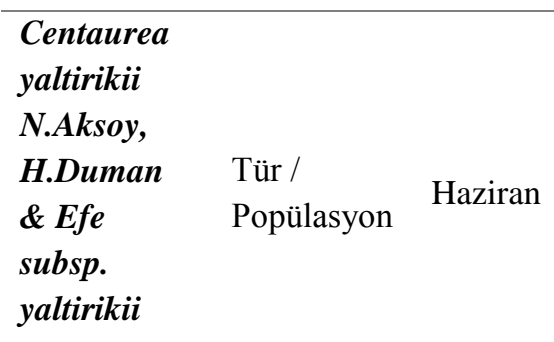

Göstergeye konu olan tür yayılış gösterdiği yerlerde birim alanda; Örtü derecesi sinıfi: 4 Örtüş oranı: \% 55-70 Sosyobilitesi: yumak, parça ve küçük koloni
Daha çok kayalık habitatlar üzerinde küçük koloniler oluşturan zaman zaman zaman münferit dağılımlar gösteren tür bu dönem içerinde çiçeklenmesine başlamıştır. 
Lythrum anatolicum

Leblebici \& Seçmen
Tür /

Popülasyon
Göstergeye konu olan tür yayılış gösterdiğ $i$ yerlerde birim alanda; Örtü derecesi sınıfi: 4

Örtüş oranı: \% 51-60

Sosyobilitesi: parça ve küçük koloni
Efteni göl kıyısı boyunca seddeye yakın kısımlarda yayılış gösteren türün popülasyonda bulunma durumu daha çok Typha latifolia ile oluşturmuş oldukları birliktelikler içerinde zaman zaman sulak alan içerinde bazen de kıyı kısmında yayılışını göstermektedir. Tür bu izleme döneminde daha çok olgun boyuna ulaşmaya çalışmakta ve üzerinde tomurcuk, çiçek benzeri yapı bulunmamaktadır.
Seseli

resinosum Tür/

Freyn \& Popülasyon Haziran

Sint.
Göstergeye konu olan tür yayılış gösterdiği yerlerde birim alanda; Örtü derecesi sınıf : 4-5 Örtüş oranı: \% 51-75 Sosyobilitesi: yama, yumak, parça ve küçük koloni
Kayalık alan habitatlarında daha çok koloniler halinde olan ve zaman zaman tekli yayılmaları da gösteren türün populasyonu kalabalık yapısı ile kayalık yüzeyleri üzerinde kendini fark ettirebilecek düzeydedir. Bu dönem içerinde çiçeklenmeye başlangıçlar olup daha çok tomurcuklanmaların tamamlanması durumu gözlemlenmektedir.

Tablo 2. Bitki Taksonlarının İzleme Planı Arazi çalışması (Ekim)

\begin{tabular}{|c|c|c|c|c|}
\hline $\begin{array}{l}\text { İzlenen } \\
\text { Çalışma } \\
\text { Konusu }\end{array}$ & $\begin{array}{l}\text { İzleme } \\
\text { Düzeyi }\end{array}$ & $\begin{array}{l}\text { Izleme } \\
\text { Zamanı }\end{array}$ & Başarı Göstergesi & İzleme Düzeyi \\
\hline $\begin{array}{l}\text { Cephalaria } \\
\text { duzceënsis } \\
\text { N.Aksoy \& } \\
\text { R.S.Göktürk }\end{array}$ & $\begin{array}{l}\text { Tür / } \\
\text { Popülasyon }\end{array}$ & Ekim & $\begin{array}{l}\text { Göstergeye konu olan } \\
\text { tür yayılış gösterdiği } \\
\text { yerlerde birim alanda; } \\
\text { Örtü derecesi sınıfi: 4-5 } \\
\text { Örtüş oranı: \% 55-65 } \\
\text { Sosyobilitesi: yama, } \\
\text { parça ve küçük koloni }\end{array}$ & $\begin{array}{l}\text { Bitki populasyonu bulunduğu alan } \\
\text { içerisinde özellikle Pinus sylvestris } \\
\text { orman altı, sınırı ve açıklık-kayalık } \\
\text { alanları üzerinde tek tek dağınık halde ya } \\
\text { da küçük koloniler oluşturacak şekilde } \\
\text { yayılış göstermektedir. Bu dönem } \\
\text { içerisinde bitki tamamen tohumlu halde } \\
\text { olup bitki kurumaya başlamıştır. }\end{array}$ \\
\hline $\begin{array}{l}\text { Centaurea } \\
\text { yaltirikii } \\
\text { N.Aksoy, } \\
\text { H.Duman \& } \\
\text { Efe subsp. } \\
\text { yaltirikii }\end{array}$ & $\begin{array}{l}\text { Tür / } \\
\text { Popülasyon }\end{array}$ & Ekim & $\begin{array}{l}\text { Göstergeye konu olan } \\
\text { tür yayılış gösterdiği } \\
\text { yerlerde birim alanda; } \\
\text { Örtü derecesi sınıfı: } 4 \\
\text { Örtüş oranı: \% 55-70 } \\
\text { Sosyobilitesi: yumak, } \\
\text { parça ve küçük koloni }\end{array}$ & $\begin{array}{l}\text { Daha çok kayalık habitatlar üzerinde } \\
\text { küçük koloniler oluşturan zaman zaman } \\
\text { zaman münferit dağılımlar gösteren tür } \\
\text { bu dönem içerinde tamamen kurumuş ve } \\
\text { üzerinde sadece tohumları kalmıştır. }\end{array}$ \\
\hline $\begin{array}{l}\text { Lythrum } \\
\text { anatolicum } \\
\text { Leblebici \& }\end{array}$ & $\begin{array}{l}\text { Tür / } \\
\text { Popülasyon }\end{array}$ & Ekim & $\begin{array}{l}\text { Göstergeye konu olan } \\
\text { tür yayılış gösterdiği } \\
\text { yerlerde birim alanda; }\end{array}$ & $\begin{array}{l}\text { Efteni göl kıyısı boyunca yayılış gösteren } \\
\text { türün popülasyonda bulunma durumu } \\
\text { daha çok Typha latifolia ile oluşturmuş } \\
\text { oldukları birliktelikler içerinde zaman }\end{array}$ \\
\hline
\end{tabular}




\begin{tabular}{|c|c|c|c|c|}
\hline \multicolumn{3}{|l|}{ Seçmen } & Örtü derecesi sınıfi: 4 & \multirow{2}{*}{$\begin{array}{l}\text { zaman sulak alan içerinde bazen de kıyı } \\
\text { kısmında yayılışını göstermektedir. }\end{array}$} \\
\hline & & & $\begin{array}{l}\text { Sosyobilitesi: parça ve } \\
\text { küçük koloni }\end{array}$ & \\
\hline $\begin{array}{l}\text { Seseli } \\
\text { resinosum } \\
\text { Freyn \& } \\
\text { Sint. }\end{array}$ & $\begin{array}{l}\text { Tür / } \\
\text { Popülasyon }\end{array}$ & Ekim & $\begin{array}{l}\text { Örtü derecesi sinıfi: 4-5 } \\
\text { Örtüş oranı: \% 51-75 } \\
\text { Sosyobilitesi: yama, } \\
\text { yumak, parça ve küçük } \\
\text { koloni }\end{array}$ & $\begin{array}{l}\text { Kayalık alan habitatlarında daha çok } \\
\text { koloniler halinde olan ve zaman zaman } \\
\text { tekli yayılmaları da gösteren türün } \\
\text { popülasyonu kalabalık yapısı ile kayalı } \\
\text { yüzeyleri üzerinde kendini fark } \\
\text { ettirebilecek düzeydedir. Bu dönem } \\
\text { içerinde tür tamamen kurumuş ve } \\
\text { üzerinde tohumları kalmıştır. }\end{array}$ \\
\hline
\end{tabular}

Son yıllarda doğal bitkilerin kentsel alanlarda yapılan bitkilendirme tasarımı çalışmalarında kullanımında artış gözlemlenmektedir. Estetik (ilginç ya da nadir görülen form, doku, renk özellikleri), çevresel (Su kullanımındaki azalma, gübre kullanımındaki azalma, yaban hayatı için uygun yaşam alanı oluşturma) ve bakım kolaylıkları nedeniyle bu bitkilerin kullanımı önem kazanmaktadır [66].

Çalışma kapsamında değerlendirilen bitkilerin peyzaj mimarlığında oluşturulabilecek uygulamalardaki kullanım olanak ve potansiyelleri belirlenmeye çalışılmıştır (Tablo 3).

Çalışmada alanında gözlemlenen 4 türe ait bitki taksonları; estetik özellikleri, yetişme ortamı özellikleri ve peyzajda kullanım yeri potansiyeli olmak üzere 3 farklı başlık altında irdelenmiştir. $\mathrm{Bu}$ inceleme sonucunda estetik özellik açısından bitkiler; bitki özellikleri, mevsimsel görünüm özellikleri, ölçü, doku, renk, form başlıkları altında 6 kriterde, yetişme ortamı açısından ise şev/eğim, kayalık, nemli/gölgeli, orman altı, kuru alanlar ve sulu alanlar olarak 6 başlık altında değerlendirilmiştir.

Bitki özellikleri açısından değerlendirildiğinde 4 türünde otsu karakter olduğu görülmektedir. Mevsimsel görünüm açısından bakıldığında ise; 3 türe ait endemik bitki taksonları yarı herdemyeşil karakterde iken sadece "Seseli resinosum" herdemyeşil karakterlidir. Bitkilerin ölçü aralıkları otsu karakterli bitki olduklarına bağlı olarak çok boy yapmamakla birlikte $30-130 \mathrm{~cm}$ arasında değişmektedir. Doku özelliklerine bakacak olursak orta dokulu olmakla birlikte sadece "Centaurea yaltirikii" bitki türü orta kaba dokulu karaktere sahiptir. Renk estetiği açısından incelendiğinde türlerin hem çiçek hem de yaprak özellikleri ile etkili oldukları tespit edilirken "Lythrum anatolicum" türü sadece çiçek özelliği ile etkili olmaktadır. Peyzajda kullanım potansiyellerine bakıldığında ise genel olarak kaya bahçelerinde, şevli alanlarda ve sulak alanlarda değerlendirilebilecekleri saptanmıştır. 
Tablo 3. Bitki Taksonlarının İzleme Planı Arazi çalışması (Haziran)

\begin{tabular}{|c|c|c|c|c|c|c|}
\hline 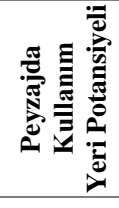 & & 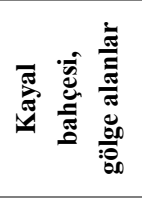 & 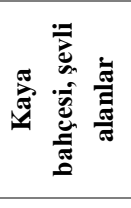 & 㐘 & 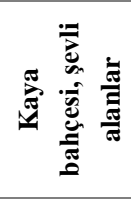 & 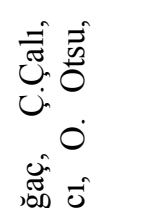 \\
\hline \multirow{6}{*}{ 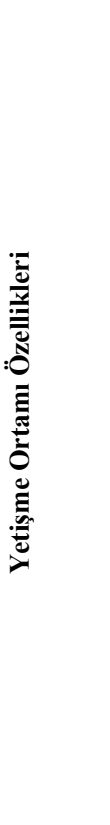 } & 咅 & ' & ' & + & ' & 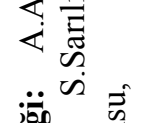 \\
\hline & 紊恋 & + & + & ' & + & 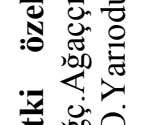 \\
\hline & हีํํㄹ & + & ' & ' & ' & \multirow{4}{*}{ 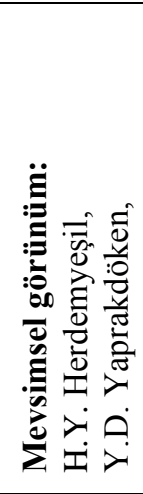 } \\
\hline & 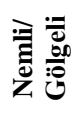 & + & ' & + & ' & \\
\hline & 兰 & + & + & ' & + & \\
\hline & 氮狺 & + & + & ' & + & \\
\hline \multirow{7}{*}{ 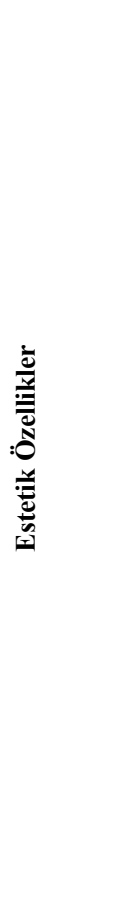 } & 节 & 害 & 苯 & $\ddot{\overline{0}}$ & 运 & \multirow{4}{*}{ 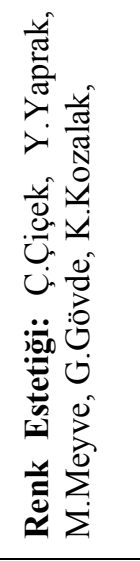 } \\
\hline & 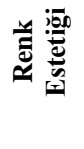 & $\vec{u}$ & 己. & $u$ & $\overrightarrow{0}$ & \\
\hline & $\frac{\vec{z}}{0}$ & 0 & $\frac{1}{0}$ & 0 & 0 & \\
\hline & 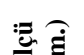 & $\varnothing_{1}$ & in & $\stackrel{\varrho}{\varrho}$ & in & \\
\hline & 0 ] & q & లి & $\infty$ & లి & \multirow{4}{*}{ 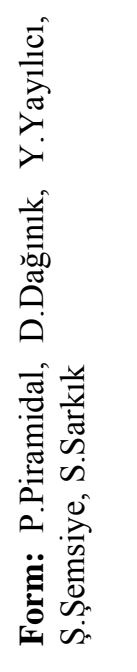 } \\
\hline & 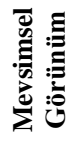 & $\stackrel{\sim}{~}$ & $\underset{\gamma}{~}$ & $\stackrel{\overbrace{}}{\nearrow}$ & 旺 & \\
\hline & 竞 & 0 & 0 & 0 & 0 & \\
\hline \multicolumn{2}{|l|}{ 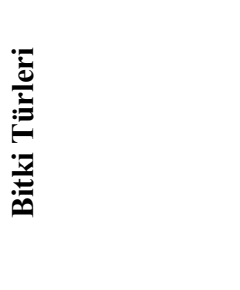 } & 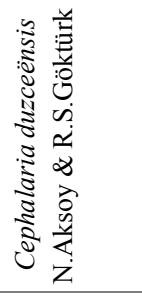 & 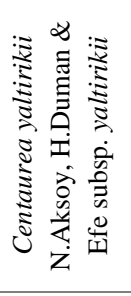 & 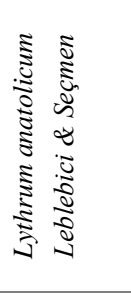 & 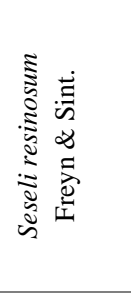 & \\
\hline
\end{tabular}




\section{IV. $\underline{\text { SONUC }}$}

Düzce, bitkisel biyolojik çeşitlilik bakımından, \% 10 endemizm oranı ile Önemli Bitki Alanları (ÖBA) kriterine sahip olup, Milli Park ya da doğa koruma alanı olabilecek nitelikte zengin biyolojik çeşitlilik merkezine sahip Batı Karadeniz'in en önemli bölgelerinden birisidir [17].

Düzce kenti elverişli iklim koşulları ile sahip olduğu coğrafik konum itibariyle vejetasyonun gelişimine ve bitki kompozisyonunun çeşitliliğine olanak sağlamaktadır. $\mathrm{Bu}$ durum bölgenin biyoçeşitliliğini arttırmakta, farklı toleranslara sahip bitki türlerinin bölgede yetişmesine imkân sunmaktadır. Bu nedenle Düzce’ye özgü bu doğal ve endemik bitki türlerine uygulamalarda yer verilmesi özellikle kent içerisinde ekolojik açıdan biyolojik dengenin sağlanmasına destek olacak hem de ekonomik açıdan da önemli derecede başarı sağlayacaktır.

İzleme alanlarında yer alan Centaurea yaltirikii subsp. yaltirikii, Cephalaria duzceënsis, Lythrum anatolicum ve Seseli resinosum endemik türleri için In-Situ ve Ex-Situ koruma sağlanmalıdır. Var olan türlerin yöre halkı tarafından tanınmaması da türlerin korunamaması açısından önemli bir sorun olarak görülmektedir. Gerek türlerin tanıtılması ve gerekse de türlere ait ortaya konulabilecek koruma statülerinin belirlenmesi korumanın sürdürülebilir olması adına önemli adımlar olacaktır. Bu bağlamda yapılacak olan bilgilendirme toplantıları, afiş ve broşürler ile kullanıcı ve yöre insanını bilinçlendirici çalışmalar bu yöndeki korumaya yönelik faaliyetleri olumlu yönde etkileyecektir. Ayrıca türlere ve onların bulundukları habitatlara yönelik olarak eylem planları oluşturulmalı ya da bu alanlarda yapılacak olan faaliyetler (yol genişletme, sulak alan ıslahı vb.) esnasında uzman görüşü alınmalıdır.

$\mathrm{Bu}$ bağlamda ele alındığında izleme alanlarında var olan türler önemli endemik ve koruma statülü türler olup bu türlere yönelik olarak ortaya çıkan en belirgin tehditler antropojenik tehditlerdir. $\mathrm{Bu}$ tehditler; yol ve bakım çalışmaları, orman içi yol ve inşaat çalışmaları, arazi kullanımına yönelik aksaklıklar, dere ve ıslah çalışmalarındaki yetersizlikler, HES vb. yapıların ortaya koyduğu olumsuz etkiler, belirli bir plan ve ön görü dışında kalan turizm ve rekreasyon faaliyetleri olarak sıralanabilir.

Çalışma kapsamında değerlendirilen endemik bitki türlerinin sene boyunca yapılan gözlemler neticesinde aylara bağlı olarak fenolojik gözlemleri yapılmış ve belirli aylara ait veriler tablolar halinde verilmiştir. Çalışmada ele alınan 4 türe ait bitki taksonlarının yetişme ortamları yerinde incelenmiş ve bilgi sahibi olunmuştur. Bu açıdan özellikle ülkemizde kentsel alanlarda yapılacak olan bitkilendirme çalışmalarında doğal bitki türlerine yer verilmesi gerektiği düşünülmekle birlikte bu bitki türlerinin üretime alınarak peyzaj mimarlığı çalışmalarında kullanılması, gerek bitki türlerinin korunması, gerekse bakım ve tesis masrafları düşük olan doğal yapıyla benzeşen uygulamaların oluşturulması açısından büyük önem taşımaktadır.

$\mathrm{Bu}$ araştırmada gerçekleştirilen arazi çalışmaları ve genel değerlendirmeler 1şığında endemik bitki türlerine ait gözlemler sonucunda aylık değişimlerin çok fazla olmadığı bunun yerine türlere yönelik olarak mevsimsel değişimlerin daha yoğun olduğu görülmüştür. Bu nedenle çalışma alanında yer alan endemik bitki türlerinin bitkilendirme tasarım çalışmalarında aylık değişimleri yerine mevsimsel değişimlerinin göz önüne ele alınması gerektiği değerlendirilmiştir. Bu bitki türlerinin peyzajda kullanım potansiyelleri değerlendirildiğinde özellikle kayalık alanlar ve yol kenarları şev alanlarında hem estetik açıdan hem de fonksiyonel yönde bu türlere yer verilmesi gerektiği düşünülmektedir. Ayrıca özellikle sulak alanlar oluştururken yapılacak olan çalışmalarda çiçek özelliğiyle ön plana çıkan ve soliter olarak etkili olan Lythrum anatolicum Leblebici \& Seçmen 
türünün ön plana çıkarılarak Düzce'ye özgü bu türlere peyzaj tasarımlarında yer verilmesi gerekmektedir.

Sonuç olarak bu çalışma kapsamına bakıldığında endemik bitki türlerinin sahip oldukları yüksek estetik ve fonksiyonel değerlerinden dolayı, bitkisel tasarımlarda yer alabilecek potansiyele sahip oldukları görülmektedir.

TEȘEKKÜR: Bu çalışma Düzce Üniversitesi Bilimsel Araştırma Projeleri tarafından desteklenmiştir (Proje no: 2015.02.01.296).

\section{$\underline{\text { V. KAYNAKLAR }}$}

[1] H. Köse, "Ege Bölgesinde doğal olarak yetişen bazı süs ağaç ağaççık ve çalı tohumlarının çimlendirme yöntemleri üzerinde araştırmalar”, Doktora tezi, Peyzaj Mimarlı̆̆ı Bölümü, Ege Üniversitesi, İzmir, Türkiye, 1997.

[2] M. Sarıbaş, "Batı Karadeniz Bölgesinde doğal olarak yetişen odunsu süs bitkileri”, I. Ulusal Süs Bitkileri Kongresi, Yalova, Türkiye, 1998, ss. 44-50.

[3] M. Topay, Z. Kaya, "Bartın-Amasra florasındaki bazı otsu süs bitkilerinin peyzaj değerlerinin saptanması ve kentsel mekanlarda kullanım olanakları", I. Ulusal Süs Bitkileri Kongresi, s: 7482 ,Yalova.

[4] B. Deniz, U. Şirin, "Samson Dağı Doğal Bitki Örtüsünün Otsu Karakterdeki Bazı Örneklerinden Peyzaj Mimarlığı Uygulamalarında Yararlanma Olanaklarının İrdelenmesi”, $A D \ddot{U}$ Ziraat Fakültesi Dergisi, c. 2, s. 2, ss. 5 - 12, 2005.

[5] B. Bekci, M. Var, G. Taşkan, "Bitkilendirme Tasarım Kriterleri Bağlamında Doğal Türlerin Kentsel Boşluk Alanlarında Değerlendirilmesi: Bartın, Türkiye”, Artvin Çoruh Üniversitesi Orman Fakültesi Dergisi, c. 14, s. 1, ss. 113-125, 2013.

[6] M. E. Barış, "Yeşil alan uygulamalarında doğal bitki örtüsünden yeterince yararlanıyor muyuz?” II. Ulusal Süs Bitkileri Sempozyumu, Antalya, Türkiye, ss. 91-95. 2002.

[7] C. Bilgili, N. Öner, İ. Aytaş," Çankiri ili parklarının bitkisel peyzaj tasarımında kullanılan doğal ağaç türlerinin belirlenmesi”, III. Uluslararası Odun Dışı Orman Ürünleri Sempozyumu, Kahramanmaraş, Türkiye, ss. 786-795, 2014.

[8] M. Atik, O. Karagüzel, "Peyzaj Mimarlığı Uygulamalarında Su Tasarrufu Olanakları ve Süs Bitkisi Olarak Doğal Türlerin Kullanım Önceliği”, TMMOB Ziraat Mühendisleri Odası Antalya Şubesi Yayını, s. 15, ss. 9-12, 2007.

[9] E. C. Özhatay, “Türkiye'nin peyzajda kullanılabilecek bazı doğal bitkileri”, Yüksek Lisans tezi, Çevre Bilimleri Bölümü, Marmara Üniversitesi, İstanbul, 2009. 
[10] I. Altman, E. J. Wohlwill, Behavior and the natural environment, New York, USA: Plenum Press, 1983.

[11] L. J. Nasar, Environmental Aesthetics (Theory, Research and Applications), Cambridge, USA: Cambridge University Press, 1988.

[12] E. E. Tarakçı, M.E. Alpak, "Mevsimsel Bitki Görünümlerinin Tercih Ve Algısal Farklı1ıklarının Belirlenmesi”, Uluslararası Bilimler Araştırma Dergisi, c. 3, s. 1, ss. 145-154, 2018.

[13] İ. Aslanboğa, Bitkilendirmenin İlkeleri, İzmir, Türkiye, T.C. Orman Bakanlığı Ege Ormancılık Araştırma Müdürlüğü Yayını, 2002.

[14] E. Eroğlu, C. Acar, "Trabzon ve Yakın Çevresi Bazı Yayla Alanlarındaki Alpin Bitkiler ve Peyzaj Mimarlığı Çalışmalarında Kullanım Potansiyelleri”, Düzce Üniversitesi Ormancılık Dergisi, c. 5 , s. 1, ss. 42-59, 2009.

[15] A. Gül, H. Özçelik, Ö. F. Uzun, "Isparta Yöresindeki Bazı Doğal Yerörtücü Bitkilerin Adaptasyonu ve Özellikleri”, Süleyman Demirel Üniversitesi, Fen Bilimleri Enstitüsü Dergisi, c. 16, s. 2, ss. 133-145, 2012.

[16] Orman Ve Su İşleri Bakanlığı Doğa Koruma ve Milli Parklar Genel Müdürlüğü IX Bölge Müdürlüğü Duzce Şube Müdürlüğü, Duzce İli Flora (Damarlı Bitkiler), Fauna (Kuşlar, Memeliler, Çiftyaşarlar, Sürüngenler, İçsu Balıkları) ve Habitat/ Ekosistem İzleme İşi Projesi Raporu, 2015.

[17] N. Aksoy, N. G. Özkan, S. Aslan, N. Koçer, "Düzce ili botanik tarihi araştırmaları", 2. Uluslararası Düzce Tarih, Kültür ve Sanat Sempozyumu, Düzce, Türkiye, ss. 409-421, 2015. 